\title{
Slug-test derived differences in bed hydraulic properties between a surge-type and a non-surge-type Svalbard glacier
}

\author{
Bernd KULESSA, ${ }^{1}$ TAVi MURRAY ${ }^{2}$ \\ ${ }^{1}$ Environmental Engineering Research Centre, School of Civil Engineering, Queen's University of Belfast, Belfast BT9 5 AG, Northern Ireland \\ E-mail:bkulessa@qub.ac.uk \\ ${ }^{2}$ School of Geography, University of Leeds, Leeds LS2 97T, England
}

\begin{abstract}
We investigate the differences in subglacial hydraulic properties between Bakaninbreen, a surge-type glacier in southern Svalbard, and midre Lovénbreen, a nonsurge-type glacier in northwest Svalbard, using slug tests. At Bakaninbreen, underlain by fine-grained glacial till and marine sediments, slug-test responses were underdamped and are analyzed with the Van der Kamp method using a fully penetrating screen. At midre Lovénbreen, underlain by metres-thick permafrost consisting of coarse clasts, ice and water, slug-test responses were overdamped and are analyzed with the Butler-Garnett method using a partially penetrating screen. We calculate typical hydraulic conductivities of $8.2 \pm 7.8 \times 10^{-3} \mathrm{~m} \mathrm{~s}^{-1}$ for Bakaninbreen, and $1.9 \pm 0.5 \times 10^{-5} \mathrm{~m} \mathrm{~s}^{-1}$ for midre Lovénbreen, after correction for a high-conductivity skin. At Bakaninbreen, late surge-induced subglacial sediment dilation probably caused marked hydraulic conductivity enhancement, which could be widespread during times of peak ice flow. We argue that the flow pathways in the permafrost beneath midre Lovénbreen are present, though limited in terms of their discharge capacity, which in combination with drilling-based observations and independent evidence suggests that midre Lovénbreen is not capable of surging.
\end{abstract}

\section{INTRODUGTION}

It has been widely recognized that where a glacier is well coupled to a layer of unconsolidated subglacial sediments, deformation of that layer can contribute significantly to glacier flow (e.g. Alley, 2000). Such deformation may either dilate or consolidate the sediments and thereby increase or decrease their permeability, and thus weaken or strengthen the material, respectively (e.g. Murray, 1994). This is particularly important for surge-type glaciers, where ice motion may be accelerated if the sediments are weak (e.g. Clarke and others, 1984). Since field evidence reflecting the coupled mechanical-hydrological processes operating in situ is still sparse, the hydraulic processes associated with subglacial sediment deformation are not well understood (e.g. Maltman and others, 2000). Slug tests can be used to determine the hydraulic properties of subglacial sediments, and may therefore aid in assessing such processes.

Slug testing involves the artificial disturbance of the static water level in a borehole by either insertion (falling-head test) or removal (rising-head test) of a sealed pipe. The recovery of the static water level is then recorded using a pressure transducer submerged in the borehole. If the borehole has established an efficient hydraulic connection with the subglacial aquifer, the characteristics of the response data can be interpreted in terms of the hydraulic properties of this aquifer. Slug tests were previously conducted at Trapridge Glacier, Yukon Territory, Canada (e.g. Stone and Clarke, 1993; Stone and others, 1997), Gornergletscher, Valais, Switzerland (Iken and others, 1996), and Haut Glacier d'Arolla, Valais, Switzerland (e.g. Kulessa and Hubbard, 1997; Kulessa, 2000). Hydraulic conductivity (and specific storage) was respectively inferred to be $\sim 5 \times 10^{-4} \mathrm{~m} \mathrm{~s}^{-1}\left(\sim 1 \times 10^{-4} \mathrm{~m}^{-1}\right), \sim 2 \times 10^{-2} \mathrm{~m} \mathrm{~s}^{-1}\left(2 \times 10^{-7}\right.$ $\mathrm{m}^{-1}$ ) and between $\sim 1 \times 10^{-2} \mathrm{~ms}^{-1}$ and $\sim 1 \times 10^{-3} \mathrm{~m} \mathrm{~s}^{-1}$ $\left(\sim 5 \times 10^{-4} \mathrm{~m}^{-1}\right)$ depending on location. In the former two cases, new interpretation schemes were proposed, while Kulessa (2000) adapted slug-test models often used in ground-water studies. Significantly for the present study, previous sensitivity analysis (e.g. Stone and Clarke, 1993) clearly demonstrated that such adaptations are valid.

Here we interpret slug-test data recorded at Bakaninbreen, a surge-type glacier in southern Spitsbergen, and at midre Lovénbreen, a non-surge-type glacier in northwest Spitsbergen, in terms of the differences in the subglacial hydraulic properties between the two types of glacier. We extend previous slug-test applications by proposing new adaptations of hydrogeological models to include glaciers underlain by sediments that are several metres thick, and consider the effects of a borehole skin caused by hot-water drilling.

\section{FIELD SITES}

Bakaninbreen is a $\sim 17 \mathrm{~km}$ long and $\sim 1-3 \mathrm{~km}$ wide polythermal valley glacier in southern Spitsbergen, Svalbard (Fig. 1). The glacier went through a prolonged surge between the mid-1980s and the mid-1990s (Murray and others, 1998), during which a surge front formed where fast-moving ice buttressed non-surge ice (Fig. 1). Upstream of this front the upper $\sim 0.5 \mathrm{~m}$ of the subglacial till and marine muds are unfrozen and actively deforming, overlying a complex mixture of permafrost and thawed sediments $\sim 10-15 \mathrm{~m}$ thick (Hambrey and others, 1996; Murray and others, 1997, 2000; Porter and others, 1997; Porter and Murray, 2001; Smith and 


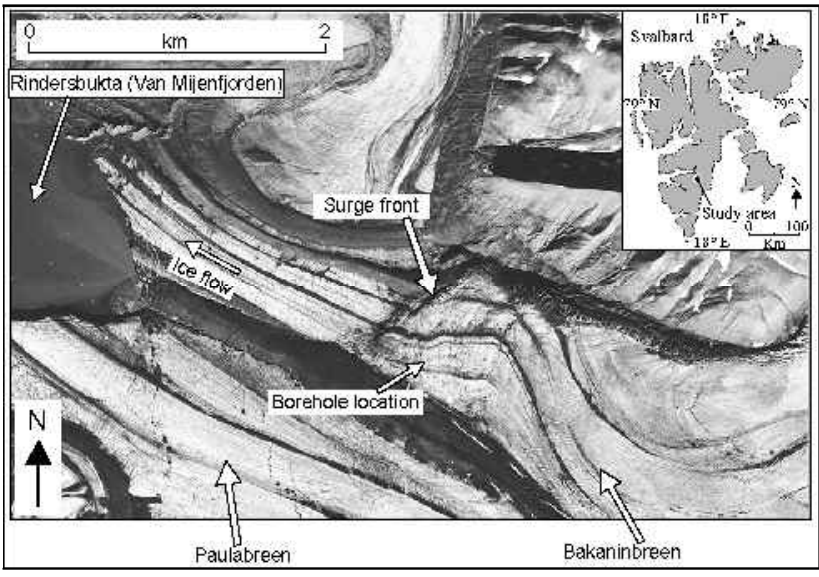

Fig. 1. Locations of Bakaninbreen in Svalbard and the study site on the glacier.

others, 2002). Dilation of the upper sediment horizon, characterized by a hydraulic conductivity of between $3.2 \times 10^{-7}$ and $7.7 \times 10^{-8} \mathrm{~m} \mathrm{~s}^{-1}$, was the dominant component of basal motion during the late surge phase (Porter and Murray, 2001). The present study was also conducted during this phase, and the borehole reported was located $\sim 150 \mathrm{~m}$ upstream of the surge front (Fig. 1).

Midre Lovénbreen is a $\sim 5 \mathrm{~km}$ long and $\sim 1 \mathrm{~km}$ wide polythermal non-surge-type (e.g. Hambrey and others, 1999; Jiskoot and others, 2000) valley glacier in northwest Spitsbergen, Svalbard (Fig. 2). The glacier is up to $\sim 180 \mathrm{~m}$ thick and underlain by a mixture of coarse clasts, ice and interstitial water (E. King, unpublished data, 2000). These permafrost deposits are several metres thick near the glacier centre line, and increase in thickness towards the glacier margins. Our experiences from hot-water drilling confirm that the ice-bed interface is poorly defined, probably due to regelation of basal ice into the underlying subglacial substrate. Attempts to sample the subglacial sediments were unsuccessful, consistent with the dominance of sediments equal to or larger than gravel-sized. The present study site is located $\sim 2 \mathrm{~km}$ upstream of the glacier terminus near the glacier centre line (Fig. 2).

\section{METHODS}

The boreholes at Bakaninbreen and midre Lovénbreen were drilled with hot, pressurized water in the summer melt seasons of 1995 and 2000, respectively. Drilling was halted when no further progress was made at a depth consistent with ice-thickness estimates from independent studies, resulting in borehole depths of $141.3 \mathrm{~m}$ at Bakaninbreen and $169.5 \mathrm{~m}$ at midre Lovénbreen. The Bakaninbreen borehole was subject to a clear water-level drop when the bed was reached, and consistently fluctuating subglacial waterpressure data recorded with a transducer installed at the base of this borehole reflect an efficient hydraulic connection with the subglacial aquifer. A noticeable water-level drop in the midre Lovénbreen borehole suggested that this borehole had also connected with the subglacial aquifer. Pressure transducers were installed in the upper portion of the boreholes to guarantee maximum data quality (e.g. Butler, 1997; Kulessa and Hubbard, 1997), and Campbell Scientific CR10 data loggers operating at a sample rate of $16 \mathrm{~Hz}$ were used for data recording. Ground-water wells

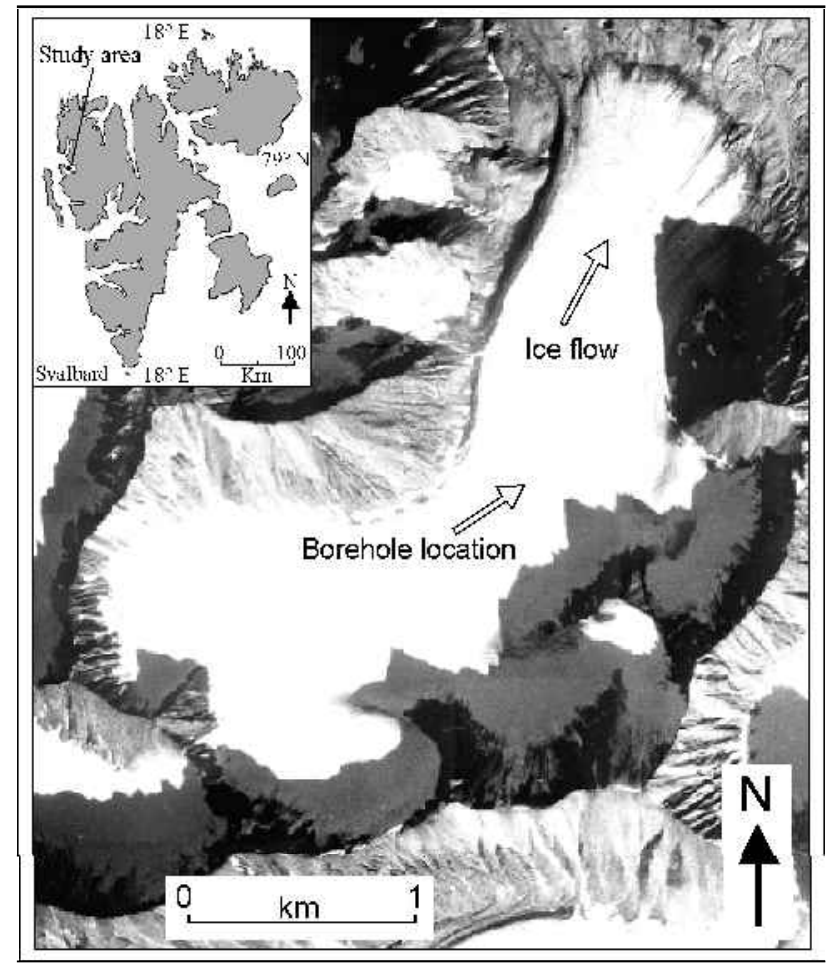

Fig. 2. Locations of midre Lovénbreen in Svalbard and the study site on the glacier.

commonly have a perforated section, or screen, that provides the hydraulic connection with the aquifer. Such well screens may either fully or partially penetrate the aquifer. Screens are absent in the case of glacier boreholes, but excavations near the borehole base due to the arrival of the hot-water jet are commonly assumed to represent an equivalent borehole screen (e.g. Stone and Clarke, 1993). This effect would be particularly pronounced where the driller is not certain whether the bed has been reached, which is commonly the case where the hydraulic connection between the borehole and the subglacial aquifer is not established immediately. In all previous applications of glacier slug tests, a fully penetrating equivalent screen was used because subglacial aquifer thicknesses were small (a few to $>10 \mathrm{~cm}$ ) (e.g. Stone and Clarke, 1993; Iken and others, 1996; Kulessa, 2000).

In addition to basal excavations, and for the first time in subglacial hydrology, we consider the formation of a borehole skin due to the effects of hot-water drilling. In ground-water studies, well skins are commonly used to describe zones of anomalously high or low hydraulic conductivity around the well screen, created by the effects of well construction. In the case of glacier boreholes, a high-conductivity skin could form around the equivalent screen as fines are preferentially flushed away from this screen, without resulting in full subglacial excavation. Sensitivity analysis reported by Hyder and others (1994) suggests that the impact of such a skin on hydraulic conductivity estimates obtained from slug tests is small, and can be further reduced by setting the radius and the length of the equivalent screen equal to the best estimates of the outer radius and the length of the skin.

Slug-test responses may be classified as overdamped (exponential, non-oscillating signal decay), underdamped (exponential, oscillating signal decay) or critically damped (transitional response). Based on theoretical considerations, Bredehoeft and others (1966) inferred that overdamped responses are typically observed when aquifer transmissivity 


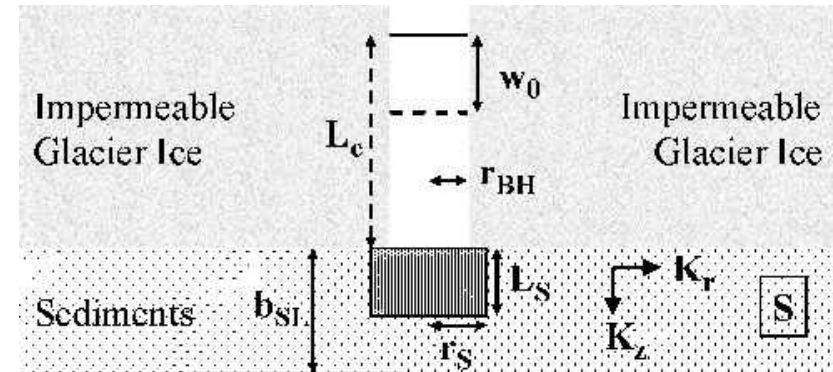

Impcrmeable Bcdrock

Fig. 3. The geometry of the flow system. A borehole of radius $r_{\mathrm{BH}}$ and effective water-column length $L_{\mathrm{e}}$ is connected to the subglacial aquifer of thickness $b_{\mathrm{SL}}$ via an equivalent screen of radius $r_{\mathrm{S}}$ and length $L_{\mathrm{S}}$. This screen partially (as indicated here) and fully penetrates the subglacial aquifers at midre Lovénbreen and Bakaninbreen, respectively. The midre Lovénbreen anisotropy in horizontal $\left(K_{\mathrm{r}}\right)$ and vertical $\left(K_{z}\right)$ hydraulic conductivity is $K_{z} K_{\mathrm{r}}^{-1}$, and the Bakaninbreen storage coefficient is $S$.

is low, and vice versa for underdamped responses. A large number of hydrogeological slug-test models have been proposed, each of which considers a particular combination of the dominant physical characteristics of the coupled borehole-aquifer flow system (e.g. Butler, 1997). These characteristics include

(i) the damping characteristics of the slug-test response,

(ii) confined vs unconfined aquifers,

(iii) fully vs partially penetrating screens,

(iv) the existence and nature of the borehole skin, and

(v) laminar vs turbulent water flow.

We assume that the subglacial aquifer at Bakaninbreen is represented by the upper, thin and easily disturbed subglacial sediment horizon. We specifically consider that (i) the slugtest response is underdamped, (ii) the subglacial aquifer is confined, (iii) the equivalent screen can be assumed to fully penetrate the subglacial aquifer, (iv) the presence of a highconductivity skin is likely, and (v) laminar water flow is dominant, as discussed below. In this case, we choose to use the Van der Kamp method (Van der Kamp, 1976) because it is the most established model that covers this particular range of physical characteristics (e.g. Hyder and others, 1994; Butler, 1997), and compared to other relevant methods it is particularly conveniently implemented using the spreadsheetbased approach described by Wylie and Magnuson (1995).

The subglacial aquifer at midre Lovénbreen is represented by the metres-thick subglacial permafrost deposits. We consider that (i) the slug-test response is overdamped, (ii) the subglacial aquifer is confined, (iii) the equivalent screen only partially penetrates the thick subglacial aquifer, (iv) the presence of a high-conductivity skin is likely, and (v) laminar water flow is dominant, as discussed below. In this case, we choose to use the Butler-Garnett method (Butler and Garnett, 2000) which is appropriate for this particular range of physical characteristics. The model is particularly conveniently implemented using the spreadsheet-based approach described by Butler and Garnett (2000).

The Van der Kamp and Butler-Garnett methods use a similar geometry of the borehole-subglacial-aquifer flow system (Fig. 3). A borehole of radius $r_{\mathrm{BH}}$ connects to the confined subglacial aquifer via an equivalent screen of radius $r_{\mathrm{S}}$, which fully penetrates the aquifer of thickness $b_{\mathrm{SL}}$ in the case of the Van der Kamp method. The Butler-Garnett method considers a partially penetrating screen of radius $r_{\mathrm{S}}$ and length $L_{\mathrm{S}}$. Removal of the sealed pipe displaces the borehole water level downwards by an initial amount $w_{0}$ (Fig. 3). The response data are characterized by a rising head, $w(t)$, until the static water level is re-established. We limit our analysis to such rising-head tests since these yield better estimates of aquifer hydraulic properties than fallinghead tests (e.g. Butler, 1997).

\section{Van der Kamp method}

The Van der Kamp method, implemented using the approach of Wylie and Magnuson (1995), uses a forward modelling approach that consists of two main steps. First, the exponentially damped cyclic fluctuation $(w(t))$

$$
w(t)=w_{0} \mathrm{e}^{-\gamma t} \cos (\omega t)
$$

is matched to the recorded slug-test data by adjusting the frequency, $\omega$, and the damping constant, $\gamma$, until the best leastsquares fit between this calculated type curve and the recorded data is obtained for a given initial water-level displacement, $w_{0}$. Van der Kamp (1976) and Butler (1997) emphasized the importance of focusing on the later, natural oscillation frequency of the recorded slug-test data during the curve-matching process to eliminate earlier, non-linear effects. If $S$ is the subglacial storage coefficient (the amount of water stored in a unit volume that extends across the whole thickness of the subglacial aquifer), $r_{\mathrm{BH}}$ is borehole radius, $r_{\mathrm{S}}$ is screen radius, $g$ is acceleration of gravity, and $n$ is index of iteration, the transmissivity of the subglacial aquifer, $T$, may be estimated iteratively in a second step using:

$$
\begin{aligned}
T_{n} & =b_{k}+a_{k} \log _{e} T_{n-1} \\
a_{k} & =r_{\mathrm{BH}}^{2} g(8 L \gamma)^{-1} \\
b_{k} & =-a_{k} \log _{e}\left[0.79 r_{\mathrm{S}}^{2}\left(g L^{-1}\right)^{0.5}\right] \\
L & =g\left(\omega^{2}+\gamma^{2}\right)^{0.5} .
\end{aligned}
$$

In the present case, convergence with a residual error of $<0.001 \%$ between two successive iterations is considered.

\section{Butler-Garnett method}

The Butler-Garnett method, implemented using the spreadsheet-based approach of Butler and Garnett (2000), considers initial matching of a type curve to the recorded slug-test data until the best least-squares fit is obtained. Subsequently, the hydraulic conductivity of the subglacial aquifer is calculated using the signal characteristics determined in the first step. Butler and Garnett (2000) give three different algorithms to calculate the appropriate type curve, the selection of which depends on whether the recorded slug-test response is underdamped, overdamped or critically damped. In the present 
case, the recorded response is overdamped, and the appropriate algorithm to use is therefore

$$
\begin{aligned}
w_{\mathrm{d}}\left(t_{\mathrm{d}}\right) & =-\left(\omega_{\mathrm{d}}^{+}-\omega_{\mathrm{d}}^{-}\right)^{-1}\left[\omega_{\mathrm{d}}^{-} \mathrm{e}^{\omega_{\mathrm{d}}^{+} t_{\mathrm{d}}}-\omega_{\mathrm{d}}^{-} \mathrm{e}^{\omega_{\mathrm{d}}^{-} t_{\mathrm{d}}}\right] \\
w_{\mathrm{d}} & =w w_{0}^{-1} \\
\omega_{\mathrm{d}} & =\left|1-\left(0.5 C_{\mathrm{D}}\right)^{2}\right|^{0.5} \\
\omega_{\mathrm{d}}^{ \pm} & =-0.5 C_{\mathrm{D}} \pm \omega_{\mathrm{d}} \\
t_{\mathrm{d}} & =t\left(g L_{\mathrm{e}}^{-1}\right)^{0.5}
\end{aligned}
$$

$C_{\mathrm{D}}$ is the dimensionless damping parameter, $g$ is gravitational acceleration, $w_{0}$ is initial water-level displacement, $L_{\mathrm{e}}$ is effective length of water column in the borehole, $t_{\mathrm{d}}$ is a dimensionless time parameter, $t$ is recorded time, $w$ is deviation of the borehole water level from static, $w_{\mathrm{d}}$ is water-level deviation normalized by the initial water-level displacement, and $\omega_{\mathrm{d}}$ is a dimensionless frequency parameter. The curvematching procedure first involves superimposing plots of the Butler-Garnett type curve $\left(w_{\mathrm{d}}\right)$ vs dimensionless time $\left(t_{\mathrm{d}}\right)$, generated using Equation (3), and the normalized recorded water-level deviations $\left(w_{\mathrm{d}}\right)$ vs recorded time $(t)$. It is imperative that both plots have the same ordinate scale, and that both abscissae start at time zero. The dimensionless damping parameter, $C_{\mathrm{D}}$, is then adjusted until the best least-squares fit between the calculated Butler-Garnett type curve and the normalized recorded water-level deviations is obtained. After curve matching, the radial hydraulic conductivity, $K_{\mathrm{r}}$, is noniteratively calculated from:

$$
\begin{aligned}
K_{\mathrm{r}}= & 0.5 t_{\mathrm{d}}{ }^{*} t^{*-1} r_{\mathrm{BH}}^{2}\left(L_{\mathrm{S}} C_{\mathrm{D}}\right)^{-1} \\
& \cdot \ln \left[0.5 L_{\mathrm{S}} r_{\mathrm{S}}^{*-1}+\left(1+0.25 L_{\mathrm{S}}^{2} r_{\mathrm{S}}^{*-2}\right)\right] \\
r_{\mathrm{S}}^{*}= & r_{\mathrm{S}}\left(K_{z} K_{r}^{-1}\right)^{0.5} \\
L_{\mathrm{e}}= & g t_{\mathrm{d}}{ }^{* 2} t_{\mathrm{d}}{ }^{*-2} .
\end{aligned}
$$

Here, $g$ is gravitational acceleration, $K_{z}$ is vertical hydraulic conductivity, $L_{\mathrm{e}}$ is effective borehole water-column length, $L_{\mathrm{S}}$ and $r_{\mathrm{S}}$ are length and radius of the equivalent screen, $r_{\mathrm{BH}}$ is borehole radius, and $t_{\mathrm{d}}{ }^{*} t^{*-1}$ is the match-point ratio. This ratio is determined by reading corresponding (equal distance from the origin on both axes) times from the recorded $\left(t^{*}\right)$ and dimensionless $\left(t_{\mathrm{d}}{ }^{*}\right)$ time axes. Note that both the match-point ratio, $t_{\mathrm{d}}{ }^{*} t^{*-1}$, and the dimensionless damping parameter, $C_{\mathrm{D}}$, depend on the scales used to plot the two time axes. This mutual dependence guarantees that the value of the horizontal hydraulic conductivity, $K_{\mathrm{r}}$, calculated from Equation (4), does not change with the scales of the time axes. The hydraulic conductivity ratio, $K_{z} K_{\mathrm{r}}^{-1}$, must be estimated from independent considerations.

\section{RESULTS}

At Bakaninbreen we focus on the underdamped slug-test responses recorded in one borehole upstream of the surge front (Fig. 1) in the 1995 summer melt season. Following an initial period of forced fluctuation, the response signal began oscillating in its natural frequency starting $\sim 8 \mathrm{~s}$ after slug removal (Fig. 4a). Unfortunately, data collection was terminated before oscillations ceased, which was also the case for a repeat slug test conducted in this borehole. The signal-tonoise ratio for this repeat test was low because the initial water-level displacement was much smaller than during the initial test. We therefore do not include this response in the present study, but nevertheless note that analysis of this

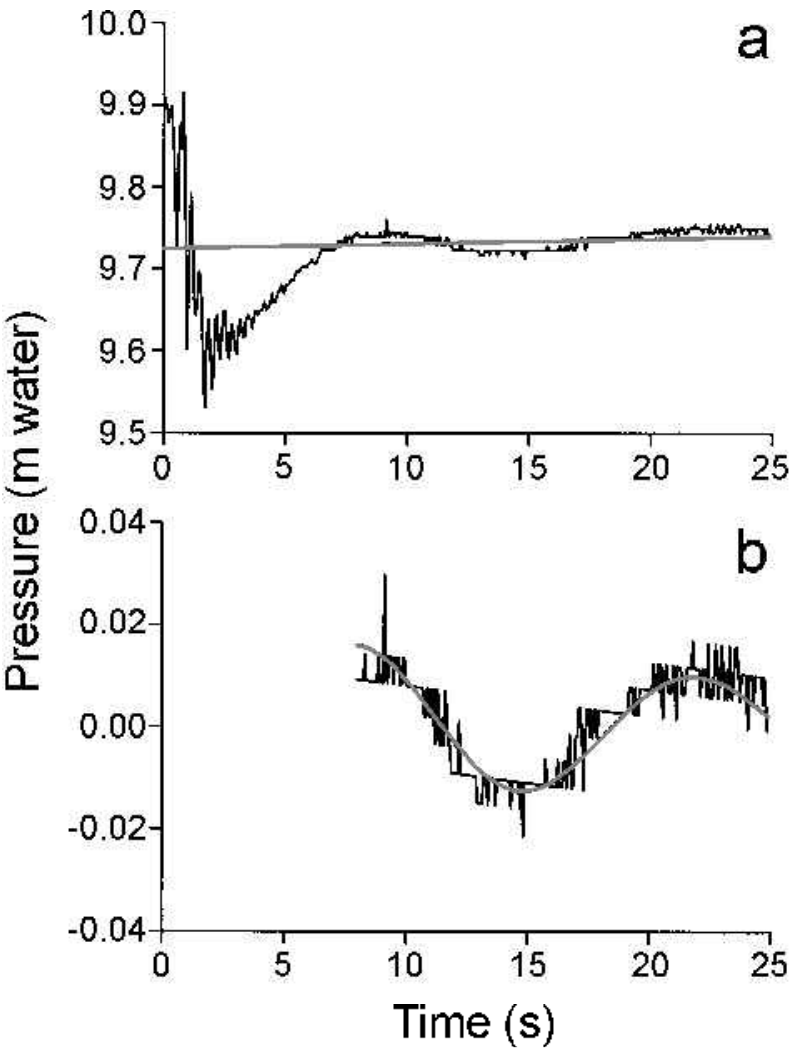

Fig. 4. Analysis of the slug-test data collected at Bakaninbreen: (a) raw data (black line) and background waterlevel change (grey line), and (b) water-level displacement corrected for background change (black line) and best-fit Van der Kamp type curve (grey line).

repeat test indicates that the results obtained from the initial slug test were reproducible.

At midre Lovénbreen, slug tests were conducted in a total of five boreholes in the 2000 summer melt season. The slugtest responses recorded in four of these boreholes were characterized by high-frequency oscillations, which commonly indicates that the boreholes were hydraulically poorly connected or even unconnected to the subglacial aquifer (e.g. Kulessa and Hubbard, 1997; Kulessa, 2000). We therefore focus on the rising-head tests recorded in the remaining borehole, which were characterized by overdamped responses. Water-level monitoring during two out of the three repetitive slug tests conducted in this borehole was, unfortunately, terminated before the pre-test water level had fully recovered. We therefore focus on the remaining test for which a full dataset is available, but nevertheless note that comparison of the incomplete and complete water-level recoveries strongly suggests that the slug-test response was reproducible. The initial water-level displacement was $\sim 0.25 \mathrm{~m}$, and the static water level was recovered after $>100 \mathrm{~s}$, allowing for a pronounced change in background level (Fig. 5a).

\section{INTERPRETATION I: BAKANINBREEN}

\section{Determination of subglacial hydraulic conductivity}

Stone and others (1997) stressed the importance of removing background water-level changes from slug-test data recorded in glacier boreholes to avoid misinterpretation, which was confirmed by Iken and others (1996) and Kulessa (2000). Removal can be accomplished by fitting either a straight line 


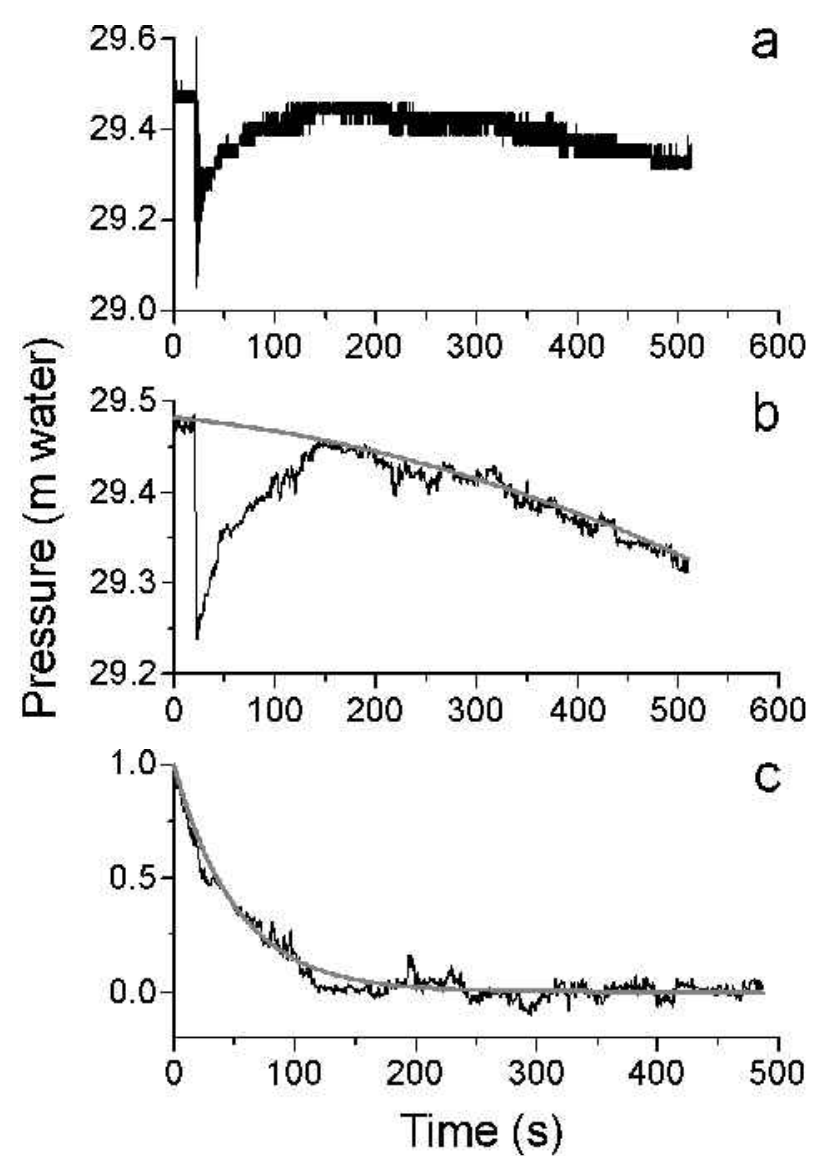

Fig. 5. Analysis of the slug-test data collected at midre Lovénbreen: (a) raw data; (b) filtered data (black line) and background water-level change (grey line); and (c) normalized water-level displacement corrected for background change and time zero (black line) and best-fit Butler-Garnett type curve (greyline).

(Iken and others, 1996; Stone and others, 1997; Kulessa, 2000) or polynomials (Iken and others, 1996) to the recorded background water-level changes, and subsequently subtracting the fitted curve from the dataset. At Bakaninbreen the background water-level change was corrected by subtracting the best-fit straight line from the raw dataset (Fig. 4a). The bestfit exponentially damped cyclic fluctuation was then calculated for and matched to the observed natural-frequency water-level oscillations using Equation (1) (Fig. 4b). Following earlier arguments, we have ignored the early, non-linear part of the response signal (e.g. Van der Kamp, 1976; Butler, 1997). The frequency and damping constant determined from curve matching are entered into Equation (2), together with the radius of the borehole, the radius of the equivalent screen, and the subglacial storage coefficient. This yields an estimate of the transmissivity of the sediment layer, which is converted to hydraulic conductivity using (e.g. Fetter, 2001, p. 100)

$$
K=T b_{\mathrm{SL}}^{-1} \text {. }
$$

In contrast to ground-water studies, the geometrical properties of the borehole-subglacial-aquifer flow system are commonly not well known in glaciological applications. We must therefore rely on best-guess estimates of these parameters in combination with rigorous sensitivity analysis. Our best-guess estimates of borehole radius $\left(r_{\mathrm{BH}}=0.05 \mathrm{~m}\right)$, equal to that used by all previous studies (e.g. Stone and Clarke, 1993; Iken and others, 1996; Kulessa, 2000), equivalent screen radius $\left(r_{\mathrm{S}}=0.2 \mathrm{~m}\right)$, storage coefficient $(S=0.03)$
Table 1. Sensitivity analysis for Bakaninbreen

\begin{tabular}{|c|c|c|c|c|}
\hline & \multicolumn{2}{|c|}{ Error range } & $\begin{array}{c}K_{\min } \\
10^{-3} \mathrm{~m} \mathrm{~s}^{-1}\end{array}$ & $\begin{array}{c}K_{\max } \\
10^{-3} \mathrm{~m} \mathrm{~s}^{-1}\end{array}$ \\
\hline$r_{\mathrm{BH}}(\mathrm{m})$ & 0.05 & $\begin{array}{l}+0.02 \\
-0.01\end{array}$ & 2.5 & 23.7 \\
\hline$r_{\mathrm{S}}(\mathrm{m})$ & 0.2 & $\begin{array}{l}+0.05 \\
-0.15\end{array}$ & 21.9 & 3.9 \\
\hline$S$ & 0.03 & $\begin{array}{l}+0.04 \\
-0.0299999\end{array}$ & 61.4 & 6.1 \\
\hline$b_{\mathrm{SL}}(\mathrm{m})$ & 0.5 & $\begin{array}{l}+0.5 \\
-0.3\end{array}$ & 20.6 & 4.1 \\
\hline
\end{tabular}

Notes: For each parameter the best-guess estimate is given with potential errors, as explained in the text. Each parameter was varied individually within the error range, resulting in the maximum and minimum hydraulic conductivities listed.

and sediment thickness $\left(b_{\mathrm{SL}}=0.5 \mathrm{~m}\right)$ are summarized in Table 1. Following earlier arguments, we set the radius and the length of the equivalent screen equal to the best estimates of the outer radius and the length of the skin (Hyder and others, 1994). The diameter of the skin was chosen to be somewhat smaller than its length since the water jet acts predominantly in the vertical and downward direction. Porter and Murray (2001) reported a specific storage of $0.064 \mathrm{~m}^{-1}$ for the sediment layer beneath Bakaninbreen, which is equivalent to a storage coefficient of $\sim 0.03$ given a sediment thickness of $0.5 \mathrm{~m}$ (e.g. Fetter, 2001, p.101). The best-guess sediment thickness $\left(b_{\mathrm{SL}}\right)$ of $0.5 \mathrm{~m}$ is equal to the best estimate reported by previous studies, and specifically equals the length of the equivalent screen since the latter is assumed to fully penetrate the subglacial flow layer.

Entering these values into Equations (2) and (5), together with the parameters obtained from curve matching, gives a best-guess hydraulic conductivity of $8.2 \times 10^{-3} \mathrm{~m} \mathrm{~s}^{-1}$ for the subglacial sediments beneath Bakaninbreen. Convergence of the computation with a residual error of $<0.001 \%$ was achieved after 12 iterations.

\section{Sensitivity analysis}

We assume that the curve-fitting procedure involved in the Van der Kamp method is accurate compared to the bestguess estimates of borehole radius, radius and length of the skin, and anisotropy ratio (e.g. Kulessa, 2000). We therefore assigned each of the four uncertain parameters a maximum and a minimum value within the limits of reason, and varied each parameter individually relative to the best-guess estimates of the three remaining parameters. For a borehole radius of $0.03 \mathrm{~m}$ or less, an equivalent screen of $>0.25 \mathrm{~m}$ and a storage coefficient of 0.05 or higher, the algorithm given in Equation (2) was found to be generally unstable, but in all other cases convergence with a residual error of $<0.001 \%$ typically resulted after $<15$ iterations. Hydraulic conductivity changes resulting from this individualized sensitivity analysis were typically well within half an order of magnitude, except for the smallest storage coefficient (Table 1). This value $\left(1 \times 10^{-7}\right)$ is approximately equivalent to the specific storage reported for Gornergletscher (Iken and others, 1996). The standard error of 
Table 2. Sensitivity analysis for midre Lovénbreen

$\begin{array}{ccc}\text { Error range } & K_{\min } & K_{\max } \\ & 10^{-5} \mathrm{~m} \mathrm{~s}^{-1} & 10^{-5} \mathrm{~m} \mathrm{~s}^{-1}\end{array}$

\begin{tabular}{lcccc}
\hline$r_{\mathrm{BH}}(\mathrm{m})$ & 0.05 & \pm 0.02 & 0.7 & 3.7 \\
$r_{\mathrm{S}}(\mathrm{m})$ & 0.5 & +0.7 & 4.4 & 0.9 \\
& & -0.4 & 2.3 & 1.6 \\
$L_{\mathrm{S}}(\mathrm{m})$ & 1.5 & \pm 1 & 1.9 & 1.3 \\
$K_{z} K_{\mathrm{r}}^{-1}$ & 1 & +2 & & \\
\hline
\end{tabular}

Notes: For each parameter the best-guess estimate is given with potential errors, as explained in the text. Each parameter was varied individually within the error range, resulting in the maximum and minimum hydraulic conductivities listed.

the hydraulic conductivity range reported in Table 1 was calculated to be $7.9 \times 10^{-3} \mathrm{~m} \mathrm{~s}^{-1}$.

We therefore conclude that the sediments beneath Bakaninbreen have a hydraulic conductivity of $8.2 \pm 7.9 \times 10^{-3} \mathrm{~m} \mathrm{~s}^{-1}$.

\section{INTERPRETATION II: MIDRE LOVÉNBREEN}

\section{Determination of subglacial hydraulic conductivity}

A band-reject fast Fourier transform filter was applied to the raw data to eliminate disturbing frequencies between 0.5 and $10 \mathrm{~Hz}$, allowing unequivocal identification of the initial water-level displacement (Fig. 5b). A consistent, non-linear background water-level change is superimposed on the recorded slug-test data (Fig. 5a), which is well approximated by a second-order polynomial (Fig. 5b). We thus remove the background water-level change by subtracting this second order polynomial from the dataset (Fig. $5 \mathrm{~b}$ ). The time-frame was adjusted by assigning time zero to the maximum waterlevel displacement. The data were then normalized with respect to this displacement, and matched to the best-fit Butler-Garnett type curve using the procedure described above (Fig. 5c). Independent confirmation for the goodness of the fit comes from the value of the effective water-column length calculated from the match-point ratio in Equation (4). This leng th was calculated to be $169 \mathrm{~m}$, which is identical to the actual value of just over $169 \mathrm{~m}$ within the uncertainty pertaining to the best estimate of borehole depth $(169.5 \mathrm{~m})$.

The value for the dimensionless damping parameter $\left(C_{\mathrm{D}}\right)$ and the match-point ratio $\left(t_{\mathrm{d}}{ }^{*} t^{*-1}\right)$ obtained from curve matching are substituted into Equation (4), together with the geometrical properties of the borehole--subglacialaquifer flow system. Our best-guess estimates of borehole radius $\left(r_{\mathrm{BH}}=0.05 \mathrm{~m}\right)$, screen radius $\left(r_{\mathrm{S}}=0.5 \mathrm{~m}\right)$ and length $\left(L_{\mathrm{S}}=1.5 \mathrm{~m}\right)$, and anisotropy ratio $\left(K_{z} K_{\mathrm{r}}^{-1}=1\right)$ are summarized in Table 2. The choice of screen radius and length was guided by two main arguments. First, due to the significant depth of the borehole and the poorly defined ice-bed interface it was difficult to determine whether the drill had reached the glacier base. We appreciate that drill water could have been pumped into the subglacial substrate for up to $\sim 30 \mathrm{~min}$. This would result in significant basal modifications, even if both the pressure and the temperature of this water were significantly reduced owing to the large depth. We spe- cifically anticipate that the ice originally contained within the subglacial substrate was probably melted, and any fine sediment flushed away from the borehole base, while the coarse clasts probably largely remained in place. Taken together, these arguments lead us to expect that a considerable high-conductivity skin formed around the equivalent screen. In reference to earlier arguments, we again adjust the radius of the equivalent screen to the likely diameter of the high-conductivity skin, and choose this diameter to be somewhat smaller than screen length. Based on the length of time ( $\leq \sim 30 \mathrm{~min}$ ) during which drill water was pumped into the bed, and the reduced pressure and temperature of this water, we estimate the skin length to be $\sim 1.5 \mathrm{~m}$, and the skin radius to be $\sim 0.5 \mathrm{~m}$. The best-guess anisotropy ratio was chosen to be 1 , assuming that the induced transient subglacial water flow was equal in all directions after correction for the high-conductivity skin.

Substitution of the four best-guess geometrical and anisotropy values listed in Table 2 into Equation (4), together with the curve-matching parameters, gives a best-guess hydraulic conductivity estimate of $1.9 \times 10^{-5} \mathrm{~ms}^{-1}$ for the clastic deposits beneath midre Lovénbreen.

\section{Sensitivity analysis}

As with the Bakaninbreen sensitivity analysis, we assume that the curve-fitting procedure involved in the ButlerGarnett method is accurate, which is in this case confirmed by matching calculated and observed effective water-column lengths. Again, each of the four uncertain parameters was varied individually within a reasonable range using the best-guess values for the three remaining parameters. The hydraulic conductivity changes were typically well within half an order of magnitude in all of these individualized cases (Table 2), with a standard error of $0.5 \times 10^{-5} \mathrm{~m} \mathrm{~s}^{-1}$.

We therefore conclude that the hydraulic conductivity of the clastic deposits beneath midre Lovénbreen has a value of $1.9 \pm 0.5 \times 10^{-5} \mathrm{~m} \mathrm{~s}^{-1}$.

\section{SYNTHESIS AND GONGLUSIONS}

Our inferences suggest that the glacial till and marine sediments beneath Bakaninbreen have a hydraulic conductivity $\left(8.2 \pm 7.8 \times 10^{-3} \mathrm{~m} \mathrm{~s}^{-1}\right)$ that is almost three orders of magnitude larger than that of the clastic deposits beneath midre Lovénbreen $\left(1.9 \pm 0.5 \times 10^{-5} \mathrm{~m} \mathrm{~s}^{-1}\right)$. A marked discrepancy of more than one order of magnitude remains even if we assume a minimum hydraulic conductivity of $4.0 \times 10^{-4} \mathrm{~m} \mathrm{~s}^{-1}$ for Bakaninbreen, and a maximum hydraulic conductivity of $2.4 \times 10^{-5} \mathrm{~m} \mathrm{~s}^{-1}$ for midre Lovénbreen, as suggested by sensitivity analysis. This matches our initial observations based on the fact that underdamped and overdamped responses, respectively, reflect materials of high and low hydraulic conductivity (Bredehoeft and others, 1966). We can now interpret our findings in the light of the other evidence collected at both glaciers.

If late-surge subglacial sediment deformation were absent, we would expect the hydraulic conductivity of the glacial till and marine sediments beneath Bakaninbreen to be noticeably smaller, and specifically to approximate textbook values $\left(\leq 10^{-6} \mathrm{~m} \mathrm{~s}^{-1}\right.$; e.g. Fetter, 2001, p. 85). Our findings are therefore consistent with, and provide unique field evidence of, marked hydraulic conductivity enhancement due to sediment dilation during the surge of Bakaninbreen. Significantly, our hydraulic 
conductivity estimate $\left(8.2 \pm 7.8 \times 10^{-3} \mathrm{~m} \mathrm{~s}^{-1}\right)$ is several orders of magnitude larger than that reported by Porter and Murray (2001) for the same sediments $\left(\sim 10^{-7}\right.$ to $\left.10^{-8} \mathrm{~m} \mathrm{~s}^{-1}\right)$ on the basis of long-term in situ borehole water-pressure and tilt-cell measurements. We agree with Stone and others (1997) that this discrepancy probably highlights the heterogeneous nature of the subglacial water system. We believe that at Bakaninbreen the glacier bed comprises a patchwork of dilated, transmissive regions of sediment interspersed with undilated, low-conductivity regions. The borehole in which the slug tests were undertaken drained, suggesting that we intersected with dilated sediments. Compared to slug tests, long-term measurements are probably sensitive to larger regions of the bed including poorly transmissive sediment patches, resulting in an average, noticeably smaller hydraulic conductivity. Since Bakaninbreen had already slowed down when the present study and that of Porter and Murray (2001) were conducted, it is likely that sediment dilation, and therefore also hydraulic conductivity enhancement, were less widespread than during times of peak or near-peak ice flow. We therefore suggest that the hydraulic conductivity values reported here $\left(8.2 \pm 7.8 \times 10^{-3} \mathrm{~m} \mathrm{~s}^{-1}\right)$ could be common for widespread areas of the glacier bed during such times, while those inferred by Porter and Murray $\left(\sim 10^{-7}\right.$ to $10^{-8} \mathrm{~m} \mathrm{~s}^{-1}$ ) could be more typical during the quiescent phase.

We believe that our findings are consistent with the presence of coarse clasts, ice and interstitial water beneath midre Lovénbreen (E. King, unpublished data, 2000). The waterflow pathways within this form of permafrost can be expected to be predominantly small and poorly connected, supporting a small hydraulic conductivity $\left(1.9 \pm 0.5 \times 10^{-5} \mathrm{~m} \mathrm{~s}^{-1}\right)$. Nevertheless, subglacial water evacuation is possible, and the magnitude of the hydraulic conductivity still appears large enough to prevent water from accumulating at the ice-permafrost interface. We noted earlier that four out of five boreholes did not connect, and argued that our experiences from drilling were consistent with regelation of basal ice into bed. It is therefore likely that many parts of the glacier are frozen to the bed. We believe that these arguments, taken together, provide compelling evidence that midre Lovénbreen is not capable of surging.

In summary, we have presented field evidence for significant hydraulic conductivity enhancement due to sediment dilation in the upper sediment horizon beneath a surging glacier. In contrast, the hydraulic conductivity of subglacial permafrost is comparatively small, despite the presence of coarse clastic deposits. The contrasting basal conditions beneath these two glaciers support the notion that midre Lovénbreen and other glaciers resting primarily on such deposits are not capable of surging (Jiskoot and others, 2000).

\section{ACKNOWLEDGEMENTS}

This research was funded by grants from the U.K. Natural Environment Research Council (NERC; GT3/9031 and GST/02/2192). H. Vereecken (Research Center Jülich, Germany) generously granted B.K. leave of absence in summer 2000, which made this study possible. A. Hiatt and P. Porter are thanked for their enthusiastic assistance with slug-test data collection in 1995. We received invaluable logistic support from M. Davey and N. Cox of the NERG Arctic
Research Base during our 2000 season on midre Lovénbreen. We thank A. Smith and J. Kohler, and the Assistant Editor, H. Engelhardt, for helpful comments on the manuscript.

\section{REFERENGES}

Alley, R. B. 2000. Continuity comes first: recent progress in understanding subglacial deformation. In Maltman, A. J., B. Hubbard and M. J. Hambrey, eds. Deformation of glacialmaterials. London, Geological Society, 171-179. (Special Publication 176.

Bredehoeft, J. D., H. H. Cooper, Jr and I. S. Papadopulos. 1966. Inertial and storage effects in well-aquifer systems: an analog investigation. Water Resour. Res., 2(4), 697-707.

Butler, J. J., Jr. 1997. The design, performance, and analysis of slug tests. Boca Raton, FL, Lewis Publishers.

Butler, J. J., Jr and E. J. Garnett. 2000. Simple procedures for analysis of slug tests in formations of high hydraulic conductivity using spreadsheet and scientific graphics software. Lawrence, KS, Kansas Geological Survey. (Open-File Report 2000-40)

Clarke, G. K. C., S. G. Collins and D. E. Thompson. 1984. Flow, thermal structure, and subglacial conditions of a surge-type glacier. Can. F. Earth Sci., 21 (2), 232-240.

Fetter, C. 2001. Applied hydrogeology. Fourth edition. Englewood Cliffs, NJ, Prentice Hall.

Hambrey, M. J., J. A. Dowdeswell, T. Murray and P. R. Porter. 1996. Thrusting and debris entrainment in a surging glacier: Bakaninbreen, Svalbard. Ann. Glaciol., 22, 241-248.

Hambrey, M. J., M. R. Bennett, J. A. Dowdeswell, N. F. Glasser and D. Huddart. 1999. Debris entrainment and transfer in polythermal valley glaciers. F. Glaciol., 45(149), 69-86.

Hyder, Z., J.J. Butler, Jr, C. D. McElwee and W. Liu. 1994. Slug tests in partially penetrating wells. Water Resour. Res., 30 (11), 2945-2957.

Iken, A., K. Fabri and M. Funk. 1996. Water storage and subglacialdrainage conditions inferred from borehole measurements on Gornergletscher Valais, Switzerland. 7. Glaciol., 42(141), 233-248.

Jiskoot, H., T. Murray and P. Boyle. 2000. Controls on the distribution of surge-type glaciers in Svalbard. 7. Glaciol., 46(154), 412-422.

Kulessa, B. 2000. Geophysical borehole investigations of subglacial drainage conditions at Haut Glacier d'Arolla, Switzerland. (Ph.D. thesis, University of Wales, Aberystwyth.)

Kulessa, B. and B. Hubbard. 1997. Interpretation of borehole impulse tests at Haut Glacier d'Arolla, Switzerland. Ann. Glaciol., 24, 397-402

Maltman, A. J., B. Hubbard and M.J. Hambrey. 2000. Deformation of glacial materials: introduction and overview. In Maltman, A. J., B. Hubbard and M.J. Hambrey, eds. Deformation of glacial materials. London, Geological Society, 1-9. (Special Publication 176.)

Murray, T. 1994. Glacial deformation. In Maltman, A., ed. The geological deformation of sediments. New York, Chapman and Hall, 73-93.

Murray, T., D. L. Gooch and G.W. Stuart. 1997. Structures within the surge front at Bakaninbreen, Svalbard, using ground-penetrating radar. Ann Glaciol., 24, 122-129.

Murray, T., J. A. Dowdeswell, D. J. Drewry and I. Frearson. 1998. Geometric evolution and ice dynamics during a surge of Bakaninbreen, Svalbard. f. Glaciol., 44(147), 263-272. (Erratum: 45(150), 1999, p. 405.)

Murray, T. and 6 others. 2000. Glacier surge propagation by thermal evolution at the bed. F. Geophys. Res., 105(B6), 13,491-13,507.

Porter, P. R. and T. Murray. 2001. Mechanical and hydraulic properties of till beneath Bakaninbreen, Svalbard. 7. Glaciol., 47(157), 167-175.

Porter, P. R., T. Murray and J. A. Dowdeswell. 1997. Sediment deformation and basal dynamics beneath a glacier surge front: Bakaninbreen, Svalbard. Ann. Glaciol., 24, 21-26.

Smith, A. M., T. Murray, B. M. Davison, A. F. Clough, J. Woodward and H. Jiskoot. 2002. Late-surge glacial conditions on Bakaninbreen, Svalbard, and implications for surge termination. 7. Geophys. Res., 107(B8), 2152 (10.1029/2001JB000475)

Stone, D. B. and G. K. C. Clarke. 1993. Estimation of subglacial hydraulic properties from induced changes in basal water pressure: a theoretical framework for borehole-response tests. F. Glaciol., 39(132), 327-340.

Stone, D. B., G. K. C. Clarke and R. G. Ellis. 1997. Inversion of boreholeresponse test data for estimation of subglacial hydraulic properties. $\mathcal{F}$. Glaciol., 43(143), 103-113.

Van der Kamp, G. 1976. Determining aquifer transmissivity by means of well response tests: the underdamped case. Water Resour. Res., 12(1), 71-77.

Wylie, A. and S. Magnuson. 1995. Spreadsheet modeling of slug tests using the Van der Kamp method. Ground Water, 33(2), 326-329. 